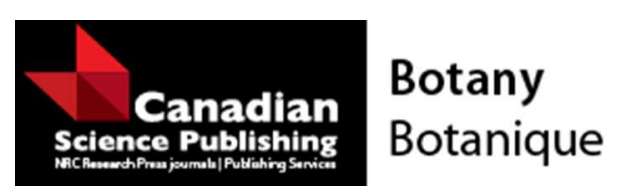

\title{
Dormancy, Storability and Germination of Seeds in Magnolia punduana (Magnoliaceae)
}

\begin{tabular}{|r|l|}
\hline Journal: & Botany \\
\hline Manuscript ID & cjb-2016-0056.R1 \\
\hline Manuscript Type: & Article \\
\hline Date Submitted by the Author: & 15 -May-2016 \\
\hline Complete List of Authors: & $\begin{array}{l}\text { Iralu, Viheno; North-Eastern Hill University, Department of Environmental } \\
\text { Upadies } \\
\text { Sciences }\end{array}$ \\
\hline & \\
\hline
\end{tabular}

\section{SCHOLARONE ${ }^{\text {m }}$}

Manuscripts 


\section{Dormancy, Storability and Germination of Seeds in Magnolia punduana (Magnoliaceae)}

Viheno Iralu and Krishna Upadhaya

Viheno Iralu (First author). Department of Environmental Studies, School of Human and Environmental Sciences, North-Eastern Hill University, Shillong- 793 022, India.

email: viheiralu@gmail.com

Phone: +918014526820

Krishna Upadhaya (Corresponding author). Department of Basic Sciences and Social Sciences, School of Technology, North-Eastern Hill University, Shillong- 793 022, India.

email: upkri@yahoo.com

Phone: +919436119857 


\begin{abstract}
Magnolia punduana Hk. f \& Th. (Syn. Michelia punduana) is a threatened tree species restricted to north-eastern India. The seeds remain dormant for 6 months after dispersal. Seed development and breaking of dormancy was investigated in the present study. Physical treatments such as water (cold, hot and boiling), acid and manual scarification proved ineffective in breaking dormancy. Matured seeds had linear and under-developed embryos at the time of dispersal with an embryo to seed length (E:S) ratio of 0.13 . Germinating seeds showed a significant increase in the embryo length with an E: S ratio of 0.36. Cold stratification (CS) at $5^{\circ} \mathrm{C}$ effectively broke dormancy. The embryo grew significantly after CS indicating the presence of 'non-deep simple' morphophysiological dormancy (MPD). Application of $\mathrm{GA}_{3}$ had a significant effect on germination and the lowest germination time with the shortest $T_{50}$ was observed in seeds treated with $3000 \mathrm{mg}^{-1} \mathrm{GA}_{3}$. $\mathrm{KNO}_{3}$ did not have an influence on breaking dormancy except in combination with $\mathrm{GA}_{3}$ which increased the germination percentage significantly. Cold stratification for 90 days and $\mathrm{GA}_{3}\left(3000 \mathrm{mg} \mathrm{l}^{-1}\right)$ at $25^{\circ} \mathrm{C}$ resulted in optimum germination. In the test for viability, seeds stored at $5^{\circ} \mathrm{C}$ showed highest viability of $66.66 \%$ after 180 days.
\end{abstract}

Key words: Dormancy, $\mathrm{GA}_{3}$, Germination, Magnolia, Stratification, Viability. 


\section{Introduction}

Magnolia punduana Hk. f. and Th. (Syn: Michelia punduana) of Magnoliaceae is an endemic tree species of Meghalaya, northeast India (Haridasan and Rao 1985; Nayar and Sastry 1990; IUCN 2014). The sub- genus Michelia comprises ca. 80 species of trees and shrubs distributed in Asian temperate, sub- tropical and tropical zones (Zhang 2007). Magnolia punduana is a middle-sized tree having a straight trunk with an average height of about $15 \mathrm{~m}$, often forming the canopy layer (Iralu and Upadhaya 2015). The species has a restricted distribution and grows in sub-tropical broadleaved forests at an elevation range of 800-1500m asl. The species was listed as 'rare' by Walter and Gillett (1998) and Nayar and Sastry (1990) and is classified as 'Data Deficient' by the IUCN Red List (Wheeler and Rivers 2015). The restricted distribution of the species coupled with exploitation for timber has made it imperative to conserve the species.

There are a number of studies on the class of dormancy in Magnolia seeds. Some studies have established that seeds of Magnolia have physiological dormancy (PD) evidenced by enhanced germination with application of $\mathrm{GA}_{3}$ (Bahaguna et al. 1988), while others are of the view that the species has morphological dormancy (MD) due to under-developed embryo at the time of maturation (Baskin and Baskin 1998). There are studies which indicate that the species has both morphological and morphophysiological dormancy (MPD) (Martin 1946; Zhou and $\mathrm{Hu}$ 1990). In addition to exhibiting seed dormancy, Magnolia seeds are shortlived. In Magnolia champaca, a species under the same sub-genus, seeds have been classified as recalcitrant (Bahuguna et al. 1987; Robbins 1988; Bisht and Ahlawat 1999). Due to the complicated propagation of Magnolia seeds, an attempt to understand seed germination and dormancy-breaking techniques have been carried out for some species such as Michelia yunnanensis (Han et al. 2010), Magnolia champaca (Fernando et al. 2013), Magnolia grandiflora (Fetouh and Hassan 2014) and Manglietiastrum sinicum (Zheng and Sun 2009). However, there is no information on dormancy- breaking approaches and germination requirements of the lesser known Magnolia punduana which is facing the threat of extinction (Iralu and Upadhaya 2015). Information on the type and class of prevailing dormancy, embryo development at maturity, dormancy-breaking techniques to speed up germination, and identifying a favourable temperature for growth will help in propagating this threatened taxon ex situ, thus, relieving threat pressures. Therefore, this study was undertaken with the following objectives:

1) Characterize the class of dormancy present by studying seed morphology, germination, and embryo development 
2) To test the effects of physical (cold, hot and boiling water treatments, manual scarification), chemical (acid scarification, $\mathrm{GA}_{3}$ and $\mathrm{KNO}_{3}$ treatments) and stratification (cold and warm) on dormancy-breaking and germination and

3) To understand the effect of storage on viability and germination of M. punduana seeds.

\section{Materials and methods}

Seed Source

Mature follicles of M. punduana were collected during August 2015 from Jarain $\left(25^{\circ} 19.016^{\prime} \mathrm{N}, 92^{\circ} 08.566^{\prime} \mathrm{E}\right)$ in the Jaintia hills of Meghalaya, northeast India. The fruits were collected from fifteen randomly distributed trees. About 2000 seeds were collected for the study. Healthy seeds were separated from those seeds that were predated and damaged by ants and insects on the forest floor in the laboratory by using the floatation method (Pipinis et al. 2011). Seeds were soaked in water for 24 hours till the arils softened. The seeds were washed manually to remove the arillus and disinfected in $0.2 \% \mathrm{KMnO}_{4}$ solution for 2 hours following Zuo (1994a). Seeds were stored under laboratory conditions $\left(24^{\circ} \pm 1^{\circ} \mathrm{C}, \mathrm{RH}\right.$ : 60 $75 \%$ ) and subjected to different treatments within 5 days of seed collection to avoid loss of viability.

\section{Moisture Content}

To determine the moisture content, three replicates of seeds weighing $10 \pm 0.01$ grams (ca. 137 seeds) each were oven dried at $80^{\circ} \mathrm{C}$ for 24 hours and the final weight was measured. Three sets of seeds weighing $10 \pm 0.01$ grams each were placed under laboratory condition and the weight was measured after 30 days to observe changes in moisture. Moisture content was calculated following ISTA (2008).

\section{Imbibition test}

In order to understand the imbibing capacity of seeds of M. punduana, 30 seeds were manually scarified using a razor blade and the initial weight of each seed was measured. Nonscarified seeds were also weighed in the same way. Seeds of both sets were placed on moist filter paper in petri dishes and kept in the laboratory. Each seed was re-weighed after 2, 4, 6, $8,10,20,30$ and 40 hours and the percentage change in mass was calculated.

\section{Germination tests}

Seeds were soaked in cold $\left(20^{\circ} \mathrm{C}\right.$ ), hot (seeds submerged in $80^{\circ} \pm 0.50^{\circ} \mathrm{C}$ until the water cooled) and boiling water $\left(2\right.$ minutes in $100^{\circ} \mathrm{C}$ and immediately transferred to cold water). The seeds were then transferred to fresh water and kept for 48 hours and changing water every 12 hours. The seeds were sown in plastic trays filled with a mixture of garden 
soil and sand in the ratio of 3:1 under laboratory condition. A control was maintained by sowing seeds without prior soaking. The trays were kept under laboratory conditions at a temperature of $24^{\circ} \mathrm{C}\left( \pm 1^{\circ} \mathrm{C}\right)$ with an average 8 hours of light $(>700$ lux $)$ and monitored at 2 day intervals for germination. For each experiment, three replicates of 50 seeds were maintained.

To test the effect of scarification, seeds were manually scarified using a sharp razor. Seeds were subjected to acid scarification by soaking in concentrated $\mathrm{H}_{2} \mathrm{SO}_{4}(95 \%)$ for 10 minutes and washed thoroughly in running water. Both manually- and acid- scarified seeds were placed in respective $150 \mathrm{~mm}$ petri plates lined with moist filter paper (Whatman No. 1) and kept under laboratory condition. For each experiment, three replicates of 30 seeds were maintained.

For cold stratification (CS), seeds were packed in sealed polybags containing moist sand and stored in the dark at a temperature of $5^{\circ} \mathrm{C}\left( \pm 1^{\circ} \mathrm{C}\right)$. Similarly, seeds were packed in sealed polybags with moist sand and placed in an incubator at a constant temperature of $25^{\circ} \mathrm{C}$ $\left( \pm 1^{\circ} \mathrm{C}\right)$ for warm stratification (WS). Germination tests for the seeds were carried out after 0 , 30, 60, 90 and 120 days of CS and WS. After each stratification period, the seeds were washed thoroughly in running water and transferred to growth chambers fitted with LED tubes ( $>4000$ lux) with a photoperiod of 8 hours. To understand the suitable temperature for germination, seeds were germinated at a constant temperature of $25^{\circ} \mathrm{C}\left( \pm 1^{\circ} \mathrm{C}\right)$ and $30^{\circ} \mathrm{C}$ $\left( \pm 1^{\circ} \mathrm{C}\right)$. For each experiment, three replicates of 30 seeds were maintained.

The effect of $\mathrm{GA}_{3}$ on breaking dormancy and germination of $M$. punduana was investigated following Han et al. (2010). Seeds were soaked in 0, 200, 500, 1000, 2000, 2500 and $3000 \mathrm{mg} \mathrm{l}^{-1} \mathrm{GA}_{3}$ for 48 hours at room temperature. The $\mathrm{GA}_{3}$ hydrated seeds were transferred to the growth chamber at a constant temperature of $25^{\circ} \mathrm{C}\left( \pm 1^{\circ} \mathrm{C}\right)$ for germination. Similarly, seeds were soaked in $0,0.1,0.5,1.0,1.5 \% \mathrm{KNO}_{3}$ for 48 hours and further transferred to the growth chamber. The combined effects of $\mathrm{GA}_{3}$ and $\mathrm{KNO}_{3}$ were tested where seeds were soaked separately in two concentrations of $\mathrm{GA}_{3}\left(200\right.$ and $\left.500 \mathrm{mg} \mathrm{l}^{-1}\right)$ for 48 hours and subsequently soaked in two concentrations of $\mathrm{KNO}_{3}(0.1 \%$ and $0.5 \%)$ for another 48 hours respectively before incubation. The germination of the seeds was monitored at an interval of every 2 days up to 60 days. For each treatment, three replicates of 30 seeds were maintained.

\section{Embryo development}

For seed and embryo morphology and dimensional characterizations, 30 seeds each at different stages of growth were examined which included: fresh seeds, seeds cold stratified 
for 100 days and germinated seeds. Fresh seeds were soaked for 24 hours and the embryos were removed and measured. Similarly, for measuring embryo growth, embryos from seeds cold stratified for 100 days were excised. These embryos were soaked in TTZ (1\%) solution for 3 hours to assess viability (Wang et al. 2005). Length of the embryos was measured using a dissecting microscope and the ratio of embryo to seed length (E: S ratio) was calculated. To determine the critical E:S ratio, 30 seeds were kept in a growth chamber $\left(25^{\circ} \pm 1^{\circ} \mathrm{C}\right.$ and 8 hours photoperiod) until the seed coats ruptured. The seeds were then removed before radicle protrusion and the average ratio was calculated (Walck et al.1999; Vandelook et al. 2007).

\section{Viability and storage}

To understand the viability characteristics of $M$. punduana seeds and identify a suitable storage conditions, four tests were conducted. In the first test, fresh, clean and disinfected seeds were packed in airtight containers and stored at room temperature $\left(24^{\circ} \pm 2^{\circ} \mathrm{C}\right.$ and $65 \%$ humidity). In the second test, seeds were packed in airtight polybags and stored at $5^{\circ} \mathrm{C}$. The third and fourth test followed a similar approach with the addition of a substrate (moist sand) and storage at constant temperature $\left(25^{\circ} \mathrm{C}\right.$ and $\left.5^{\circ} \mathrm{C}\right)$ respectively. Seed viability was determined using the TTZ assay (Enescu 1991) and seeds were tested for viability after $15,30,45,60$ and 90 days. As seeds stored at $5^{\circ} \mathrm{C}$ remained viable even after 90 days of storage, these seeds were further monitored up to 6 months. For each treatment, three replicates of 30 seeds were maintained.

\section{Data analysis}

For each replication in each treatment, the germination percentage was calculated using the formula:

$\mathrm{G}(\%)=\mathrm{n} / \mathrm{N} \times 100$

Where, $\mathrm{n}$ is the number of germinated seeds and $\mathrm{N}$ is the total number of seeds.

Mean germination time was calculated using the formula: $\frac{n 1+n 2+n 3 \ldots}{N}$

Where, $\mathrm{n} 1, \mathrm{n} 2, \mathrm{n} 3 \ldots=$ the number of days taken by individual seeds to germinate, $\mathrm{N}=$ Total number of seeds.

The time to $50 \%$ of total germination $\left(T_{50}\right)$ was calculated by following Farooq et al. (2006):

$T_{50}=\mathrm{t}_{\mathrm{i}}+\left[\left(\mathrm{N} / 2-\mathrm{n}_{\mathrm{i}}\right)\left(\mathrm{t}_{\mathrm{j}}-\mathrm{t}_{\mathrm{i}}\right)\right] / \mathrm{n}_{\mathrm{j}}-\mathrm{n}_{\mathrm{i}}$

Where, $\mathrm{N}$ is the final number of emergence and $\mathrm{n}_{\mathrm{i}}, \mathrm{n}_{\mathrm{j}}$ cumulative number of seeds germinated by adjacent counts at times $t_{i}$ and $t_{j}$, respectively when $n_{i}<N / 2<n_{j}$. 
To determine the effect of different treatments on germination analysis of variance (ANOVA) was used with Tukey's least significant difference $(\mathrm{p}<0.05)$. Assumptions of ANOVA were met through test for normality of variables (Kolmogorov-Smirnov test) and homogeneity of group variances (Levene's test) using SPSS (version 20). Means and standard errors of germination percentages, embryo lengths and viability test were calculated.

\section{Results}

Imbibition

The result from the imbibition test revealed that both the non- scarified and scarified seeds imbibed water during the initial 6 hours at different rates (Fig. 1). However, the increase in weight was not significant $(\mathrm{p}>0.05)$ and the seeds did not show any difference in weight after 12 hours. Increase in the weight of non- scarified and scarified seeds after 40 hours was $3 \%$ and $6 \%$ respectively.

\section{Germination test}

Seeds soaked in cold water 48 hours prior to sowing, germinated to $44 \%$. The mean germination time was $213 \pm 3.55$ days $\left(T_{50}=40.28\right.$ days $)$. Seeds did not respond to the hot and boiling water treatment. The seeds without any treatment (control) germinated to $78 \%$ with a mean germination of $212 \pm 1.79\left(T_{50}=38.04\right.$ days $)$. There was no significant difference in the germination time with seeds that were subjected to soaking and the control $(p>0.05)$. Manual scarification of seeds reduced germination to $20 \%$ and seeds subjected to acid scarification did not germinate (Table 1).

CS effectively broke dormancy in seeds of M. punduana. Seeds stratified for 30 days at $5^{\circ} \mathrm{C}$ took an average of $18.71 \pm 0.64$ days and $29.29 \pm 1.30$ days to germinate at $25^{\circ} \mathrm{C}$ and $30^{\circ} \mathrm{C}$ respectively. With the increase in stratification time, there was a steady decline in the mean number of days for germination. After 120 days of CS, the average days for germination were reduced to $10.68 \pm 0.36$ days and $12.97 \pm 0.50$ days at $25^{\circ} \mathrm{C}$ and $30^{\circ} \mathrm{C}$ respectively. Results of ANOVA reveal that mean germination days after the four stratification periods (30,60, 90 and 120 days) at $25^{\circ} \mathrm{C}$ and $30^{\circ} \mathrm{C}$ respectively differed significantly $(p<0.05)$. However, there was no significant difference in germination of seeds stratified for 90 days and 120 days ( $>0.05)$ under both temperature regimes. A statistically significant difference was observed in the number of days for germination of seeds incubated at $25^{\circ} \mathrm{C}$ and $30^{\circ} \mathrm{C}$ after 30 days of cold stratification $(\mathrm{p}<0.05)$.

Germination increased with increasing period of cold stratification and the highest percentage (93.33\%) was observed after 90 days of CS for both temperature regimes. A decline in germination percentage was observed after 120 days of CS for both temperatures 
(Fig. 2). $T_{50}$ decreased from $30(6.7 \pm 1.75$ and $12.38 \pm 2.72)$ to $60(3.10 \pm 0.76$ and $4.61 \pm 0.99)$ days of CS followed by an increase up to 90 days $(6.25 \pm 1.49$ and $6.04 \pm 1.47)$ for the seeds incubated at $25^{\circ} \mathrm{C}$ and $30^{\circ} \mathrm{C}$ respectively. With prolonged stratification, $T_{50}$ further declined at 120 days under both temperatures (Fig. 2). Therefore, cold stratification broke dormancy in M. punduana seeds, with more rapid germination observed in seeds stratified for 30 days (Fig. 2). WS did not have any effect in breaking dormancy.

Application of $\mathrm{GA}_{3}$ had a marked effect on the germination of seeds. There was a steady rise in the germination percentage with the increase in concentration of $\mathrm{GA}_{3}$. At higher concentration, the number of days required for germination also declined. The highest germination percentage $(76.66 \pm 5.77 \%)$ with $T_{50}$ of 1 day was observed in seeds treated with $3000 \mathrm{mg} \mathrm{l}^{-1} \mathrm{GA}_{3}$ (Table 1). The germination percentage of seeds under the control condition was lowest $(6.66 \pm 3.33 \%)$. Results from multiple comparison tests between the various concentrations of $\mathrm{GA}_{3}$ on germination showed a significant difference between seeds treated in $200 \mathrm{mg}^{-1} \mathrm{GA}_{3}$ with all higher concentrations of $\mathrm{GA}_{3}(\mathrm{p}<0.05)$ except for $500 \mathrm{mg} \mathrm{l}^{-1}$ (Table 1). Overall, $\mathrm{KNO}_{3}$ had no influence in breaking seed dormancy with very low germination percentage (14\%). When $\mathrm{KNO}_{3}$ was combined with GA3, the percent germination increased significantly, more so than the seeds treated in $200 \mathrm{mg} \mathrm{l}^{-1}$ and $500 \mathrm{mg}$ $1^{-1} \mathrm{GA}_{3}$ alone (Table 1). The results obtained from the application of plant growth regulators (Gibberellic acid and potassium nitrate) on germination is given in table 1 .

\section{Embryo development and growth}

Seeds of M. punduana had a mean weight of $109.00 \pm 1.00 \mathrm{mg}$ at maturity. The seeds were oval-ellipsoid or ellipsoid in shaped with an average seed length of $7.13 \pm 0.11 \mathrm{~mm}$. There was a significant difference in the growth and development of the embryo from the time of dispersal to the time of germination $(p<0.01)$. The embryo was situated at the base of the seeds and was enclosed by the fleshy endosperm. The embryos in fresh seeds were small and measured $0.93 \pm 0.03 \mathrm{~mm}$ with an $\mathrm{E}: \mathrm{S}$ ratio of $0.13 \pm 0.01$. Embryo length after 100 days of CS measured $1.30 \pm 0.04 \mathrm{~mm}$, with an E:S ratio of $0.18 \pm 0.01$. Germinating seeds showed a significant increase in the embryo length $(2.53 \pm 0.18 \mathrm{~mm})$ with an E:S ratio of $0.36 \pm 0.03$. There was a significant difference $(p<0.01)$ in the length of embryos of germinating seeds when compared with fresh seeds and stratified seeds.

\section{Moisture content, Viability and Storage}

The moisture content of fresh seeds dried in the oven at $80^{\circ} \mathrm{C}$ for $24 \mathrm{~h}$ was $26.43 \pm 0.31 \%$. Seeds kept at room temperature for 30 days showed a decline in the moisture content $(17.82 \pm 0.18 \%)$. Viability of seeds stored in airtight containers and kept at room 
temperature declined to $43.33 \%$ after 15 days with complete loss of viability after 30 days of storage. Seeds stored at $5^{\circ} \mathrm{C}$ showed a viability percentage of $70 \%$ after 15 days that declined gradually to $46.66 \%$ and $23.33 \%$ after the $30^{\text {th }}$ and $45^{\text {th }}$ day respectively. Seeds in moist sand stored at $25^{\circ} \mathrm{C}$ remained $100 \%$ viable in the initial 15 days. A steady decline in viability was observed and after 90 days $(16.66 \%)$. The highest viability was observed in seeds stored moist at $5^{\circ} \mathrm{C}$ after 6 months with $66.66 \%$ viability (Table 2 ).

\section{Discussion}

Seeds of M. punduana did not show any sign of germination under laboratory conditions upto 6 months (212 days) indicating the prevalence of dormancy in the species. Seed coat scarification tests failed to overcome seed dormancy, thus, nullifying the presence of physical dormancy. Embryos in fresh seeds of M. punduana were small and located at the tapering base of the seeds. The embryos were differentiated into cotyledons and radicle with an E:S ratio of 0.13 at the time of dispersal. The species exhibited a 'basaltype' embryo (Martin 1946), characteristic of embryos restricted to the lower half of the seeds with abundant endosperm. Basal type embryos are usually common in medium to large seeds with cotyledons that are usually rudimentary and obscure (Martin 1946). Several studies on seeds of Magnoliaceae members (Magnolia accuminata, Liriodendron tulipfera) have established that they have rudimentary embryos (Martin 1946; Baskin and Baskin 1998). The seeds of M. punduana can be classified as having linear and under-developed embryos (Martin 1946; Baskin and Baskin 1998).

The dormancy in seeds of M. punduana induced by under-developed embryos indicates that seeds have morphological and physiological or morphophysiological dormancy. The embryos were small and differentiated into cotyledons and radicle that continued to grow inside the seeds after dispersal indicating morphological dormancy. According to Nikolaeva (1977) and Baskin and Baskin (2007), seeds of this species have non-deep physiological dormancy as the species satisfies a wider range of conditions including $\mathrm{GA}_{3}$-induced germination, response to $\mathrm{CS}$ and fruits ripening in dry storage evidenced by the continued ripening of fruits within the follicles post collection. A similar case of CS-induced germination has been reported in M. yunnanensis (Han et al. 2010; Zuo 1994a, Zuo 1994b). Under natural conditions, the seeds of the species undergo a period of cold stratification (soil temperature $=8^{\circ} \mathrm{C}$ ) during winter (November to February) and it may be considered as a crucial period for embryo growth and development. Therefore, the low viability and germination of seeds stored at $25^{\circ} \mathrm{C}$ under laboratory conditions may be due to absence of cold stratification. M. punduana seeds showed physiological changes in response to 
temperature. The seeds ripen in the month of August to September and germination under natural condition occurs in the month of March the following year. Thus, during the progression from dormancy to non-dormancy, the temperature gradient shifts from cold (8 $\left.{ }^{\circ} \mathrm{C}\right)$ to warm $\left(17.9^{\circ} \mathrm{C}\right)$. Germination that progresses from a lower to higher temperature has been classified under Type-1 Non Deep PD (Baskin and Baskin 2007). CS effectively broke dormancy in M. punduana with up to $93.33 \%$ of seeds germinating after $90 \mathrm{~d}$ (Fig. 2). WS did not aid in overcoming dormancy.

Based on the rate of radicle protrusion and germination percentage (Fig. 2), a temperature of $25^{\circ} \mathrm{C}$ can be considered as the suitable temperature for growth tested. Based on our results, embryo growth was found to be evident in seeds incubated at $25^{\circ} \mathrm{C}$ after $\mathrm{CS}$ at $5^{\circ} \mathrm{C}$. Thus, MPD present in M. punduana can be categorised as 'non-deep simple' (Baskin and Baskin 1998). Similar CS induced dormancy breaking has been reported in many species of Michelia such as M. yunnanensis (Han et al. 2010), M. maudiae (Shi et al. 1986) and M. platypetala (Zhou and Hu 1990).

Application of $\mathrm{GA}_{3}$ effectively broke seed dormancy in $M$. punduana and this treatment can be used as a substitute to CS. There was an increase in germination percentage with the increase in the concentration of $\mathrm{GA}_{3}$. The successful implementation of $\mathrm{GA}_{3}$ in breaking seed dormancy has been reported in other species such as Michelia chapensis (Zhou 1990) and Manglietsia insignis (Zhou and Hu 1990)

Though the stimulatory action of potassium nitrate has been reported by many researchers (Roberts and Smith 1977; Bewley and Black 1982; Hilshort and Karssen 2000) in species like Chenopodium album (Saini et al. 1985), including ferns (Scheuerlein et al. 1985), the application of $\mathrm{KNO}_{3}$ however, was not effective in overcoming the dormancy in seeds of M. punduana unless $\mathrm{GA}_{3}$ was used simultaneously The combined effect of $\mathrm{KNO}_{3}$ and $\mathrm{GA}_{3}$ significantly increased germination in seeds. This could be attributed to the fact that nitrate decreases the abscisic acid (ABA) content in seeds that is responsible for dormancy, whereas $\mathrm{GA}_{3}$ promotes germination (Hilhorst and Karssen 1992).

A decline in moisture content over a short period of time reveals that the seed is of Intermediate type (Hong and Ellis 1996). In the test for viability, it was observed that seeds stored in dry airtight containers and in polybags remained viable for the initial 15 days but lost viability within 45 days. However, the addition of moist sand prolonged the life of the seeds up to 90 days indicating moisture requirement. Seeds stored in moist sand at $5^{\circ} \mathrm{C}$ survived for almost 6 months. Thus, based on the moisture content and the storage behaviour, seeds of M. punduana can be best classified as intermediate or semi- recalcitrant. 


\section{Conclusion}

From the study, it can be concluded that seeds of $M$. punduana exhibit simple morphophysiological dormancy. A pre-treatment of cold stratification or application of $\mathrm{GA}_{3}$ can effectively break dormancy. CS for 90 days and $\mathrm{GA}_{3}\left(3000 \mathrm{mg} \mathrm{l}^{-1}\right.$ ) were the most effective period and concentration respectively for optimum germination at a temperature of $25^{\circ} \mathrm{C}$. $\mathrm{GA}_{3}$ can be used as a substitute for breaking dormancy. CS on the other hand is the best option for storage as seeds stored at $5^{\circ} \mathrm{C}$ showed the highest viability (66.66\%) after 180 days. The information and results acquired from this study can be incorporated in making seed germination protocols for mass production and reintroduction of the species in its natural habitat, thus, relieving threat pressures from anthropogenic activities. The results can also contribute to ex situ conservation of the species.

\section{Acknowledgement}

The financial support received from the University Grants Commission (UGC) in the form of fellowship to the first author (Grant no.: F1-17.1/2013-14/RGNF-2013-14-ST-NAG43868/(SA-III/website) is acknowledged.

\section{References}

Bahuguna, V.K., Rawat, M.M.S., and Naithani, K.C. 1987. Investigation on the seed of Michelia champaca Linn. for perfection of optimum conditions of storage. Indian For. 113: $243-248$.

Bahuguna, V.K., Rawat, M.M.S., and Naithani, K.C. 1988. Study on dormancy and treatment to enhance germination of champ (Michelia champaca, Linn.) seed. Indian For. 114: 317-319.

Baskin, C.C., and Baskin, J.M. 1998. Seeds: Ecology, Biogeography, and Evolution of Dormancy and Germination. Academic Press, San Diego, USA.

Baskin, C.C., and Baskin, J.M. 2007. A revision of Martin's seed classification system, with particular reference to his dwarf-seed type. Seed Sci. Res. 17: 11-20. doi: $10.1017 / \mathrm{S} 0960258507383189$. 
Bewley, J.D., and Black, M. 1982. Physiology and Biochemistry of Seeds in Relation to Germination. 2. Viability, Dormancy and Environmental Control. (Berlin: SpringerVerlag).

Bisht, N.S., and Ahlawat, S.P. 1999. Seed Technology. SFRI Information Bulletin No. 7. State Forest Research Institute, Itanagar, India.

Enescu, V. 1991. The tetrazolium test of viability. In: Tree and shrub seed handbook, chapter 9. International Seed Testing Association ISTA. Zurich.

Farooq, M., Basra, S.M.A., Afzal, I., and Khaliq, A. 2006. Optimization of hydropriming techniques for rice seed invigoration. Seed Sci. Technol. 34: 507-512. doi: $10.15258 /$ sst.2006.34.2.25.

Fernando, M.T.R., Gehan Jayasuriya, K.M.G., Walck, J.L., and Wijetunga, .A.S.T.B. 2013. Identifying dormancy class and storage behaviour of champak (Magnolia champaca) seeds, an important tropical timber tree J. Natn. Sci. Foundation Sri Lanka 41(2):141146. doi: 10.4038/jnsfsr.v41i2.5708.

Fetouh, M.I., and Hassan, F.A. 2014. Seed germination criteria and seedling characteristics of Magnolia grandiflora L. trees after cold stratification treatments. Int. J. Curr. Microbiol. App. Sci. 3(3): 235-241. Available from http://www.ijcmas.com/vol-3-3 [accessed 26 February 2016].

Han, C.Y., Welbaum, G., and Long, C.L. 2010. Seed dormancy and germination of Michelia yunnanensis (Magnoliaceae). Sci. Hortic. 124: 3-87. doi: 10.1016/j.scienta.2009.11.021.

Haridasan, K., and Rao, R.R. 1985. Forest Flora of Meghalaya - Vol I. Bishen Singh and Mahendrapal Singh, Dehra Dun. 
Hilhorst, H.W.M., and Karssen, C.M., 1992. Seed dormancy and germination: the role of abscisic acid and gibberellins and the importance of hormone mutants. Plant Growth Regul. 11: 225- 238. doi:10.1007/BF00024561

Hilhorst, H.W.M., and Karssen, C.M., 2000. Effect of chemical environment on seed germination. In: Fenner, M. (Ed.), Seeds: The Ecology of Regeneration in Plant Communities. CABI Publishing, New York, pp. 293-309.

Hong, T.D., and Ellis, R.H. 1996. A protocol to determine seed storage behaviour. IPGRI Technical Bulletin No. 1 (eds. J.M.M. Engels \& J. Toll), International Plant Genetic Resources Institute, Rome, Italy. Available from https://www.cbd.int/doc/casestudies/tttc/seedstorage.pdf [accessed 26 February 2016].

Iralu, V., and Upadhaya, K. 2015. Notes on Magnolia punduana Hk. f. \& Th. (Magnoliopsida: Magnoliales: Magnoliaceae): an endemic and threatened tree species of northeastern India. JoTT 7(9): 7573-7576. doi: 10.11609/JoTT.o4238.7573-6.

International Seed Testing Association (ISTA). 2008. International rules for seed testing (2008/1 ed., Vol. 5). Bassersdorf, Switzerland.

IUCN. 2014. The IUCN Red List of Threatened Species. Version 2014.2. http:/www.iucn redlist.org.

Martin, A.C. 1946. The comparative internal morphology of seeds. Am. Midl. Nat. 36: 513660. Available at http://www.jstor.org/stable/2421457 [assessed 26 February 2016].

Nayar, M.P., and Sastry, A.R.K. 1990. Red Data Book of Indian Plants - Vol. I. Botanical Survey of India, Calcutta, pp. 192.

Nikolaeva, M.G. 1977. Factors controlling the seed dormancy pattern. In Khan, A.A. (Ed.) The physiology and biochemistry of seed dormancy and germination. pp. 51-74. 
Pipinis, E., Milios, E., Smiris, P., and Gioumousidis, C. 2011. Effect of acid scarification and cold moist stratification on the germination of Cercis siliquastrum L. seeds. Turk. J. Agric. For. 35: 259-264. doi: 10.3906/tar-1003-848.

Robbins, A.M.J. 1988. Storage of champ (Michelia champaca) seed. Banko Janakari 2: 5557.

Roberts, E.H., and Smith, R.D. 1977. Dormancy and the pentose phosphate pathway. In: Khan, A.A. (ed.) The Physiology and Biochemistry of Seed Dormancy and Germination. North Holland Publishing, Amsterdam, pp. 385-411.

Saini, H.S., Bassi, P.K., and Spencer, M.S. 1985. Seed Germination in Chenopodium album L. relationships between nitrate and the effects of plant hormones. Plant Physiol. 77: $940-943$

Scheuerlein, R., Mader, U., and Haupt, W. 1985. Phytochrome mediated fernspore germination: sensitivity to red light is increased by $\mathrm{NH}_{4} \mathrm{NO}_{3}$. In: Book of abstracts, European Symposium on Photomorphogenesis in Plants, 1985, Wageningen, abstract 118.

Shi, X.H., Yu, Z.L., Jin, S.Q., Shi, Z.L., and Zhou, J.H. 1986. Research on the physiology of seed dormancy of Michelia maudiae. Plant Physiol. Commun. 3: 17-19 (in Chinese).

Vandelook, F., Bolle, N., and Assche, J.A.V. 2007. Seed dormancy and germination of the European Chaerophyllum temulum (Apiaceae), a member of a trans-Atlantic genus. Ann. Bot. 100: 233-239. PMID: 17556382

Walck, J.L., Baskin, J.M., and Baskin, C.C. 1999. Seeds of Thalictrum mirabile (Ranunculaceae) require cold stratification for loss of non-deep simple morphophysiological dormancy. Can. J. Bot. 77: 1769-1776. doi: 10.1139/b99-149. 
Walter, K.S., and Gillett, H. J. 1998. IUCN Red List of Threatened Plants. Compiled by the World Conservation Monitoring Centre. IUCN - the World Conservation Union, Gland, Switzerland and Cambridge. pp. 862.

Wang, L.L., Wang, G.L., and Liu, D.Y. 2005. Preliminary studies on seed of the endangered Magnolia sieboldii. J. Anhui. Normal Univ. 1: 72-75 (in Chinese).

Wheeler, L., and Rivers, M.C. 2015. Magnolia punduana. The IUCN Red List of Threatened Species 2015: e.T31237A2802522.

Zhang, X.H. 2007. Advances in research of Michelia Linn. Guihaia 5: 712-719 (in Chinese, English abstract).

Zheng, Y.L., and Sun, W.B. 2009. Seed Germination of Huagaimu, a Critically Endangered Plant Endemic to Southeastern Yunnan, China. Horttechnology 19(2): 427- 431.

Zhou, Y.X. 1990. Preliminary study on the characteristics of dormancy and germination of Michelia chapensis. J. Central-South For. Coll. 2: 165-170 (in Chinese).

Zhou, Y.X., and Hu, C.Z. 1990. Preliminary study on the characteristics of dormancy and germination of Michelia platypetala. For. Sci. Technol. 8: 7-11 (in Chinese)

Zuo, J.B. 1994a. The analysis of seed characteristic of Michelia yunnanensis. Guizhou For Sci. Technol. 2: 44-46 (in Chinese).

Zuo, J.B. 1994b. The propagation test of Michelia yunnanensis. Guizhou For. Sci. Technol. 3: 52-54 (in Chinese). 
Table 1. Effects of physical treatments (water and scarification), $\mathrm{GA}_{3}, \mathrm{KNO}_{3}$ and combination of $\mathrm{GA}_{3}$ and $\mathrm{KNO}_{3}$ on number of days for mean germination, germination percentage and time to $50 \%$ germination $\left(T_{50}\right)$ of $M$. punduana seeds $( \pm \mathrm{SEM})$.

\begin{tabular}{|c|c|c|c|}
\hline Treatments & $\begin{array}{c}\text { Mean Germination } \\
\text { (days) }\end{array}$ & $\begin{array}{c}\text { Germination } \\
(\%) \\
\end{array}$ & $T_{50}$ (days) \\
\hline \multicolumn{4}{|l|}{ Water } \\
\hline No treatment & $212.62 \pm 1.79^{\mathrm{a}}$ & $78.00 \pm 1.15$ & $31.77 \pm 3.39$ \\
\hline Cold $\left(20^{\circ} \mathrm{C}\right)$ & $213.32 \pm 3.25^{\mathrm{a}}$ & $44.00 \pm 4.61$ & $38.00 \pm 4.28$ \\
\hline $\operatorname{Hot}\left(80^{\circ} \mathrm{C}\right)$ & 0.00 & 0.00 & 0.00 \\
\hline Boiling $\left(100^{\circ} \mathrm{C}\right)$ & 0.00 & 0.00 & 0.00 \\
\hline \multicolumn{4}{|l|}{ Scarification } \\
\hline Manual & $207 \pm 1.58$ & $20.00 \pm 0.00$ & $38.88 \pm 3.89$ \\
\hline Acid $\left(95 \% \mathrm{H}_{2} \mathrm{SO}_{4}\right)$ & 0.00 & 0.00 & 0.00 \\
\hline \multicolumn{4}{|l|}{$\mathrm{GA}_{3}\left(\mathrm{mg} \mathrm{l}^{-1}\right)$} \\
\hline 0 & 0.00 & $6.66 \pm 3.33$ & - \\
\hline 200 & $24.78 \pm 1.69^{\mathrm{a}}$ & $46.66 \pm 3.84$ & $9.66 \pm 2.40$ \\
\hline 500 & $21.21 \pm 0.93^{\mathrm{ab}}$ & $48.88 \pm 2.22$ & $1.00 \pm 0.00$ \\
\hline 1000 & $19.06 \pm 0.92^{b}$ & $53.33 \pm 0.00$ & $6.40 \pm 1.76$ \\
\hline 2000 & $17.91 \pm 0.81^{\mathrm{b}}$ & $75.55 \pm 1.92$ & $4.25 \pm 1.89$ \\
\hline 2500 & $17.90 \pm 0.87^{\mathrm{b}}$ & $66.66 \pm 3.84$ & $4.93 \pm 1.89$ \\
\hline 3000 & $14.17 \pm 0.58$ & $76.66 \pm 5.77$ & $1.00 \pm 0.00$ \\
\hline \multicolumn{4}{|l|}{$\mathrm{KNO}_{3}(\%)$} \\
\hline 0 & 0.00 & 0.00 & - \\
\hline 0.1 & $48.00 \pm 10.50^{\mathrm{a}}$ & $11.10 \pm 2.22$ & $21.00 \pm 16.00$ \\
\hline 0.5 & $29.20 \pm 1.74^{\mathrm{ab}}$ & $16.66 \pm 1.92$ & $9.37 \pm 1.93$ \\
\hline 1.0 & $32.50 \pm 3.40^{\mathrm{abc}}$ & $13.33 \pm 3.85$ & $20.50 \pm 4.35$ \\
\hline 1.5 & $23.40 \pm 4.25^{\mathrm{c}}$ & $16.66 \pm 1.92$ & $9.00 \pm 4.71$ \\
\hline \multicolumn{4}{|l|}{$\begin{array}{l}\mathrm{GA}_{3}\left(\mathrm{mg} \mathrm{l}^{-1}\right)+\mathrm{KNO}_{3} \\
(\%)\end{array}$} \\
\hline 0 & 0.00 & 0.00 & - \\
\hline $200 \mathrm{GA}_{3}+0.1 \mathrm{KNO}_{3}$ & $20.05 \pm 1.13^{\mathrm{a}}$ & $69.99 \pm 1.92$ & $9.05 \pm 2.67$ \\
\hline $500 \mathrm{GA}_{3}+0.5 \mathrm{KNO}_{3}$ & $20.65 \pm 1.35^{\mathrm{a}}$ & $56.66 \pm 1.92$ & $8.39 \pm 2.32$ \\
\hline
\end{tabular}

Note: For each treatment, means followed by the same letter do not differ significantly at $p<$ 0.05 (Tukey's multiple range test). 
Table 2. Viability of M. punduana seeds subjected to different storage conditions.

\begin{tabular}{lcccccc}
\hline \multicolumn{1}{c}{ Storage type } & \multicolumn{5}{c}{ Viability (\%) } \\
\cline { 2 - 7 } & $\mathbf{1 5}$ days & $\mathbf{3 0}$ days & $\mathbf{4 5}$ days & $\mathbf{6 0}$ days & $\mathbf{9 0}$ days & $\mathbf{1 8 0}$ days \\
\hline Airtight container at room temperature & $43.33 \pm 3.33$ & - & - & - & - & - \\
$5^{\circ} \mathrm{C}$ in airtight polybags & $70 \pm 5.77$ & $46.66 \pm 3.33$ & $23.33 \pm 3.33$ & - & - & - \\
Storage in moist sand $\left(25^{\circ} \mathrm{C}\right)$ & 100 & $86.66 \pm 3.33$ & $60 \pm 5.77$ & $46.66 \pm 8.81$ & $16.66 \pm 3.33$ & - \\
Storage in moist sand $\left(5^{\circ} \mathrm{C}\right)$ & 100 & 100 & $96.66 \pm 3.33$ & $93.33 \pm 6.66$ & $86.66 \pm 3.33$ & $66.66 \pm 6.66$ \\
\hline
\end{tabular}

$( \pm$ SEM, $n=150)$. 


\section{Figure captions}

Fig. 1. Imbibition of non-scarified and scarified seeds of Magnolia punduana.

Fig. 2. Germination percentage and time to $50 \%$ germination $\left(T_{50}\right)$ under $25^{\circ} \mathrm{C}$ and $30^{\circ} \mathrm{C}$ after different periods of cold stratification $( \pm$ SEM). 


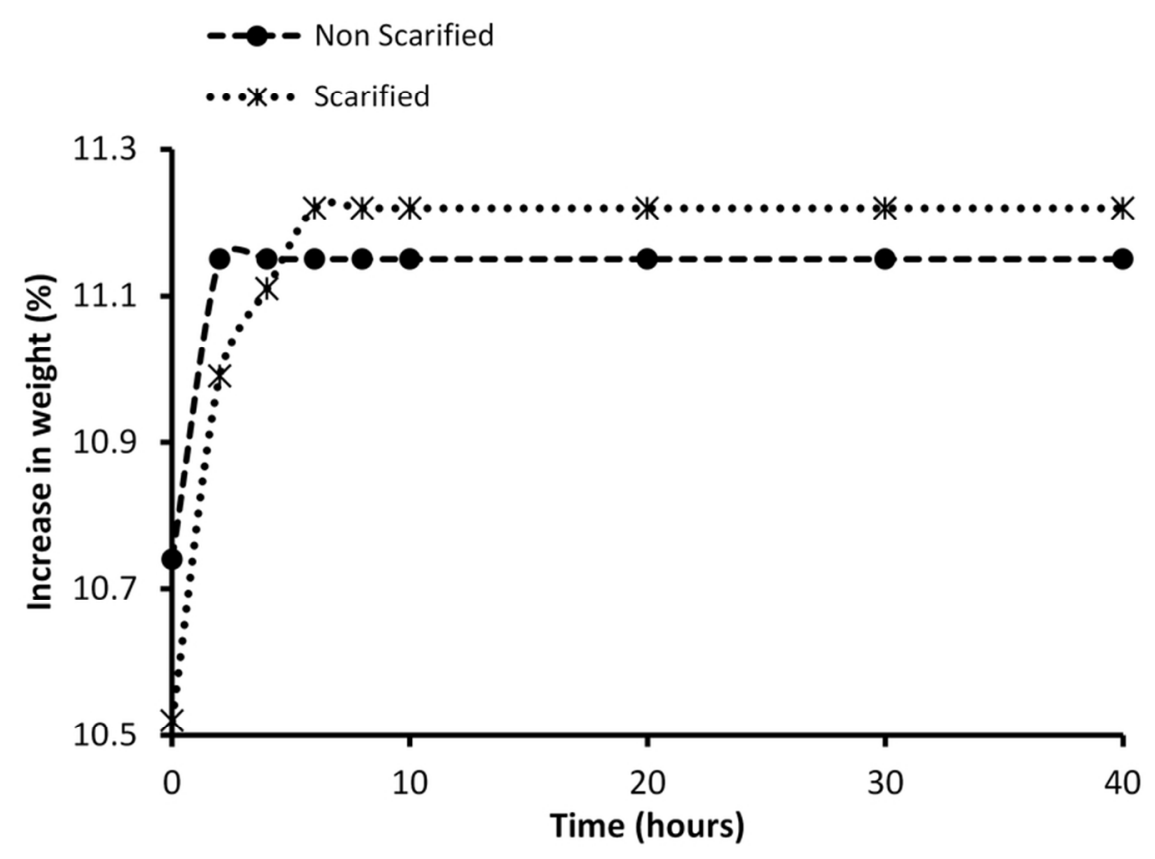

Fig. 1. Imbibition of non-scarified and scarified seeds of Magnolia punduana $84 \times 57 \mathrm{~mm}(300 \times 300$ DPI $)$ 

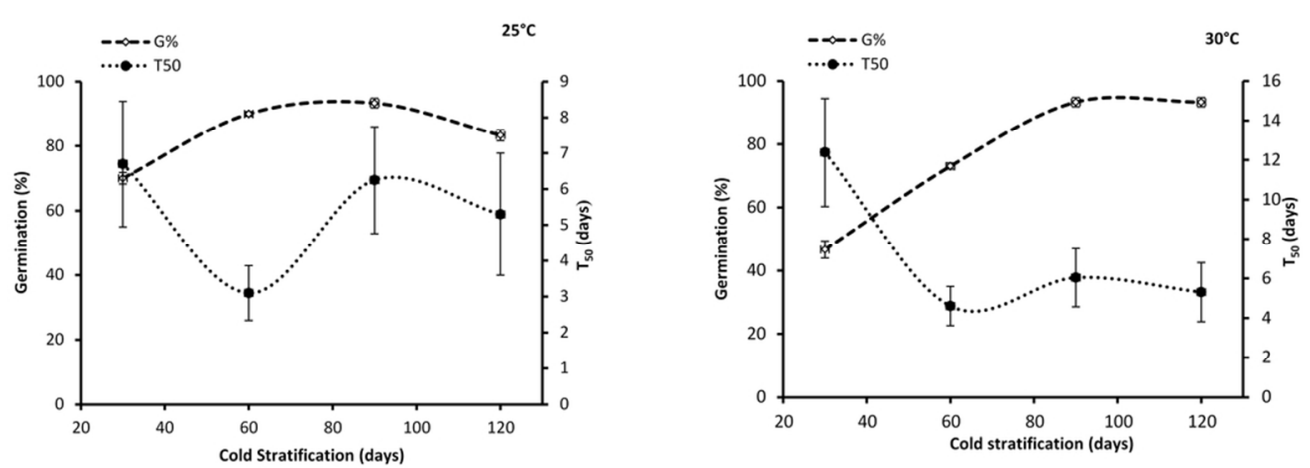

Fig. 2. Germination percentage and time to $50 \%$ germination $\left(T_{50}\right)$ under $25^{\circ} \mathrm{C}$ and $30^{\circ} \mathrm{C}$ after different periods of cold stratification ( \pm SEM)

$89 \times 31 \mathrm{~mm}(300 \times 300 \mathrm{DPI})$ 